\title{
BIOSYNTHESIS OF BENASTATIN A
}

\author{
Takayuki Aoyama ${ }^{\dagger}$, Hiroshi Naganawa ${ }^{\dagger}$, Yasuhiko Muraoka $^{\dagger}$, \\ TAKAAKI AOYAGI ${ }^{\dagger+\dagger}$ and TOMIO TAKEUCHI ${ }^{\dagger}$ \\ †Institute of Microbial Chemistry, \\ 3-14-23 Kamiosaki, Shinagawa-ku, Tokyo 141, Japan \\ ${ }^{\dagger \dagger}$ Showa College of Pharmaceutical Sciences, \\ Machida-city, Tokyo 194, Japan
}

(Received for publication June 9, 1992)

\begin{abstract}
The biosynthesis of benastatin A, produced by Streptomyces sp. MI384-DF12, has been studied by feeding experiments with ${ }^{14} \mathrm{C}$ - and ${ }^{13} \mathrm{C}$-labeled compounds followed by measurement of radioactivity and ${ }^{13} \mathrm{C}$ NMR analysis. The results indicate that benastatin $\mathrm{A}$ is derived from two methionine units and fourteen acetate units, condensed in the "head-to-tail" fashion of typical polyketide biosynthesis.
\end{abstract}

Benastatin A, a new inhibitor of glutathione S-transferase, has been found in the culture broth of Streptomyces sp. MI384-DF12 ${ }^{1)}$. It has unique structure which consist of the chromophore of 13,13-dimethyl-8-oxo-benzo[a]naphthacene-2-carboxylic acid and a pentyl group bonded to C-3 of the chromophore $^{2)}$ (Fig. 1). The closely related natural products possessing a benzo[a]naphthacene quinone skeleton, G-2N, G-2A $\mathrm{A}^{3)}$ and $\mathrm{KS}-619-1^{4)}$, were reported previously, and the biosynthetic studies of a benzo $[a]$ naphthacene quinone skeleton were also carried out concerning with benanomicins $\mathrm{A}$ and $\mathrm{B}^{5)}$ and pradimicin $\mathrm{A}^{63}$, previously. The biosynthetic pathway of benastatin $\mathrm{A}$ was studied since it did not contain a quinone skeleton.

In this paper, we report the biosynthetic origin of the carbon atoms in benastatin $\mathrm{A}$ based on feeding experiments with ${ }^{14} \mathrm{C}$ - and ${ }^{13} \mathrm{C}$-labeled compounds.

\section{Materials and Methods}

Labeled Compounds

Sodium $\left[1-{ }^{14} \mathrm{C}\right]$ acetate, sodium $\left[1-{ }^{14} \mathrm{C}\right]$ propionate and $\mathrm{L}-\left[\right.$ methyl $\left.-{ }^{14} \mathrm{C}\right]$ methionine were purchased from New England Nuclear, Boston, U.S.A. The specific radioactivities are shown in Table 1. Sodium $\left[1-{ }^{13} \mathrm{C}\right]$ acetate $\left(99 \%{ }^{13} \mathrm{C}\right.$ enriched), sodium $\left[2-{ }^{13} \mathrm{C}\right]$ acetate $(99 \%)$, sodium $\left[1,2-{ }^{13} \mathrm{C}_{2}\right]$ acetate $(99 \%)$ and $\mathrm{L}-\left[\right.$ methyl $\left.{ }^{13} \mathrm{C}\right]$ methionine $(99 \%)$ were obtained from Aldrich Chemical Co.

\section{General Procedure}

Radioactivities were measured in a $20-\mathrm{m} 1$ vial with a Beckman LS9800 liquid scintillation analyzer by using $10 \mathrm{ml}$ of Aquasol-2 (NEN Research Products) as a scintillation cocktail. ${ }^{13} \mathrm{C}$ NMR spectra were obtained in $\mathrm{MeOH}-d_{4}$ on a Jeol JNM-GX400 NMR spectrometer at $100 \mathrm{MHz}$. Chemical shifts were recorded in ppm down field from internal TMS. Preparative TLC was done on a Silica gel $60 \mathrm{~F}_{254}$ plate $0.25 \mathrm{~mm}$ thick (E. Merck, Art. No. 5715) using $\mathrm{CHCl}_{3}-\mathrm{MeOH}(4: 1)$ as the developing solvent. Benastatin $\mathrm{A}$ on the TLC
Fig. 1. Structure of benastatin A.<smiles>CC=CC=Cc1cc2ccc3c(O)c4c(cc3c2c(O)c1C(=O)O)C(C)(C)c1cc(O)cc(O)c1C4=O</smiles> 
plates was detected either by its color or by use of UV light ( $254 \mathrm{~nm})$.

Fermentation

A loopful of slant culture of Streptomyces sp. MI384-DF12 (FERM P-11270) was inoculated into $110 \mathrm{ml}$ of a seed medium containing galactose $2.0 \%$, dextrin $2.0 \%$, Bacto Soytone $1.0 \%$, corn steep liquor $0.5 \%,\left(\mathrm{NH}_{4}\right)_{2} \mathrm{SO}_{4} 0.2 \%$ and $\mathrm{CaCO}_{3} 0.2 \%(\mathrm{pH} 7.4)$ in a $500-\mathrm{ml}$ Erlenmeyer flask and cultured at $30^{\circ} \mathrm{C}$ for 72 hours on a rotary shaker $(180 \mathrm{rpm})$. Two $\mathrm{ml}$ of this seed culture were transferred into $110 \mathrm{ml}$ of the production medium consisting of glycerol 2.0\%, soy bean meal (Ajinomoto Co., Inc.) $1.5 \%, \mathrm{~K}_{2} \mathrm{HPO}_{4} 0.1 \%$ and $\mathrm{CoCl}_{2} \cdot 6 \mathrm{H}_{2} \mathrm{O} 0.0005 \%$ (pH 6.2 adjusted with $1 \mathrm{M} \mathrm{KH}_{2} \mathrm{PO}_{4}$ before sterilization) in a $500-\mathrm{ml}$ Erlenmeyer flask and cuitured at $27^{\circ} \mathrm{C}$ on a rotary shaker $(180 \mathrm{rpm})$. For the feeding experiments of ${ }^{14} \mathrm{C}$-labeled compounds, the additions were made at 48 hours after inoculation and the fermentation was continued for 48 hours. In the case of ${ }^{13} \mathrm{C}$-labeled compounds, singly labeled acetates and labeled methionine were dissolved in water at a concentration of $40 \mathrm{mg} / \mathrm{ml}$, and doubly labeled acetate was dissolved in water at a concentration of $80 \mathrm{mg} / \mathrm{ml}$ and diluted with an equal volume of non-labeled acetate solution $(80 \mathrm{mg} / \mathrm{ml})$. An aqueous solution $(0.25 \mathrm{ml})$ of each ${ }^{13} \mathrm{C}$-labeled compound were added at 36,42 and 48 hours after inoculation, and the cultures were then incubated further for 24 hours.

\section{Determination of Incorporation Ratios of ${ }^{14} \mathrm{C}$-Labeled Compounds}

The culture broth was filtered and separated into the mycelial cake and the culture filtrate. The mycelial cake was extracted with $70 \mathrm{ml}$ of $\mathrm{MeOH}$; the extract was filtered and concentrated in vacuo to an aqueous solution. The solution was combined with the culture filtrate and extracted with an equal volume of EtOAc ( $\mathrm{pH}$ 2). The extract was concentrated to dryness under reduced pressure and purified by preparative TLC. A yellowish zone containing radioactive benastatin A (Rf value: 0.46 ) was collected and suspended in the scintillation cocktail. The radioactivity of ${ }^{14} \mathrm{C}$-labeled benastatin $\mathrm{A}$ was measured with a liquid scintillation analyzer and total incorporation ratios were calculated.

\section{Preparation of ${ }^{13} \mathrm{C}$-Labeled Benastatin A Sodium Salt}

Sodium $\left[1-{ }^{13} \mathrm{C}\right]$ acetate $(30 \mathrm{mg})$, sodium $\left[2-{ }^{13} \mathrm{C}\right]$ acetate $(30 \mathrm{mg})$, sodium $\left[1,2-{ }^{13} \mathrm{C}_{2}\right]$ acetate $(30 \mathrm{mg})$ and $\mathrm{L}-\left[\right.$ methyl $\left.\mathrm{H}^{13} \mathrm{C}\right]$ methionine $(30 \mathrm{mg})$ were fed to each flask. The culture broth was filtered and separated into the mycelial cake and the culture filtrate. Extractions by $\mathrm{MeOH}$ and EtOAc were performed as described above. The crude powder was further purified by a reverse phase HPLC using a Capcell Pak $\mathrm{C}_{18}$ column $(2.0 \times 25 \mathrm{~cm}$, flow rate $8 \mathrm{ml} / \mathrm{minute}$, using GiLson's system) with a solvent mixture of $\mathrm{CH}_{3} \mathrm{CN}-\mathrm{H}_{2} \mathrm{O}-\mathrm{AcOH}(78: 22: 1)$. The eluate containing benastatin $\mathrm{A}$ was evaporated to dryness to obtain a yellow powder. In order to prepare benastatin A sodium salt, the yellow powder was suspended with $20 \mathrm{ml}$ of water and extracted with $20 \mathrm{ml}$ of EtOAc ( $\mathrm{pH} 2)$. After the concentration of the EtOAc layer, three equivalents of $\mathrm{CH}_{3} \mathrm{COONa} \cdot 3 \mathrm{H}_{2} \mathrm{O}$ was added to the solution of benastatin $\mathrm{A}$ in $\mathrm{MeOH}(10 \mathrm{mg} / \mathrm{ml})$ and the mixture was stirred at room temperature for 10 minutes. The solution was concentrated to dryness and chromatographed on Sephadex LH-20 $(1.3 \times 110 \mathrm{~cm})$ using $\mathrm{MeOH}$ as eluant. Benastatin A sodium salt was eluted and evaporated to give ${ }^{13} \mathrm{C}$-labeled benastatin $\mathrm{A}$ sodium salt (1.6 3.3 mg).

\section{Results and Discussion}

As shown in Table $1,\left[1-{ }^{14} \mathrm{C}\right]$ acetate and $\mathrm{L}-\left[\right.$ methyl $\left.-{ }^{14} \mathrm{C}\right]$ methionine were efficiently incorporated into benastatin $\mathrm{A}$, but $\left[1-{ }^{14} \mathrm{C}\right]$ propionate was negligibly incorporated. These results suggest that the benastatin skeleton is derived from a polyacetate intermediate and $C$-methylation occurs.

The feeding experiments using $\left[1-{ }^{13} \mathrm{C}\right],\left[2-{ }^{13} \mathrm{C}\right]$ and $\left[1,2-{ }^{13} \mathrm{C}_{2}\right]$ acetates and $\mathrm{L}-\left[\right.$ methyl $\left.-{ }^{13} \mathrm{C}\right]-$ methionine to the cultures of Streptomyces sp. MI384-DF12 were carried out in order to clarify the biosynthetic origin of the chromophore and the pentyl group of benastatin $\mathrm{A}$. The ${ }^{13} \mathrm{C}$ NMR spectra of benastatin A sodium salt derived from $\left[1-{ }^{13} \mathrm{C}\right],\left[2-{ }^{13} \mathrm{C}\right]$ and $\left[1,2-{ }^{13} \mathrm{C}_{2}\right]$ acetates are shown in Figs. 2 and 3. 
Table 1. Incorporation of ${ }^{14} \mathrm{C}$-labeled compounds into benastatin $\mathrm{A}$.

\begin{tabular}{|c|c|c|c|c|}
\hline \multirow{2}{*}{ Labeled compounds } & \multirow{2}{*}{$\begin{array}{c}\text { Specific } \\
\text { activity } \\
(\mathrm{mCi} / \mathrm{mol})\end{array}$} & \multicolumn{2}{|c|}{ Radioactivity (dpm) } & \multirow{2}{*}{$\begin{array}{c}\text { Incorporation } \\
\text { into benastatin A } \\
(\%)\end{array}$} \\
\hline & & Fed & Benastatin A & \\
\hline Sodium $\left[1-{ }^{14} \mathrm{C}\right]$ acetate & 59.0 & $3.51 \times 10^{7}$ & $1.94 \times 10^{6}$ & 5.5 \\
\hline Sodium $\left[1-{ }^{14} \mathrm{C}\right]$ propionate & 57.0 & $4.26 \times 10^{7}$ & $3.82 \times 10^{4}$ & 0.09 \\
\hline $\mathrm{L}-\left[\right.$ Merhyl $\left.-{ }^{14} \mathrm{C}\right]$ methionine & 55.0 & $4.43 \times 10^{7}$ & $8.99 \times 10^{6}$ & 20.3 \\
\hline
\end{tabular}

Fig. 2. ${ }^{13} \mathrm{C}$ NMR spectra of benastatin $\mathrm{A}$ sodium salt derived from sodium $\left[1-{ }^{13} \mathrm{C}\right]$ and $\left[2-{ }^{13} \mathrm{C}\right]$ acetates and $\mathrm{L}-\left[\right.$ methyl- $\left.{ }^{13} \mathrm{C}\right]$ methionine in $\mathrm{CD}_{3} \mathrm{OD}$.

$\mathrm{L}-\left[M e-{ }^{13} \mathrm{C}\right] \mathrm{Met}$
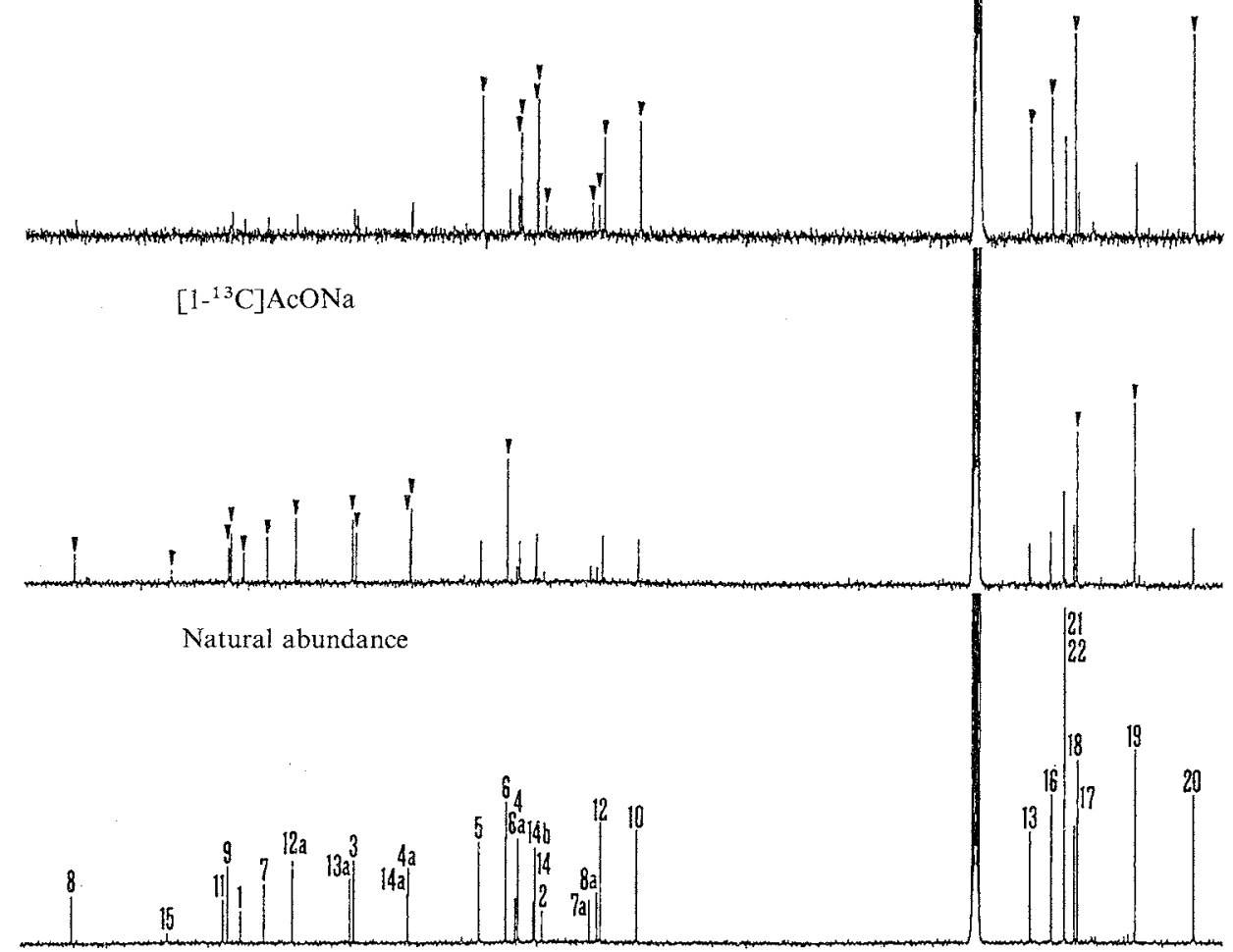

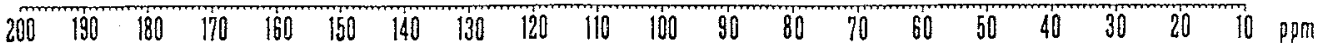


Fig. 3. ${ }^{13} \mathrm{C}$ NMR spectrum of benastatin $\mathrm{A}$ sodium salt derived from sodium $\left[1,2-{ }^{13} \mathrm{C}_{2}\right]$ acetate in $\mathrm{CD}_{3} \mathrm{OD}$.
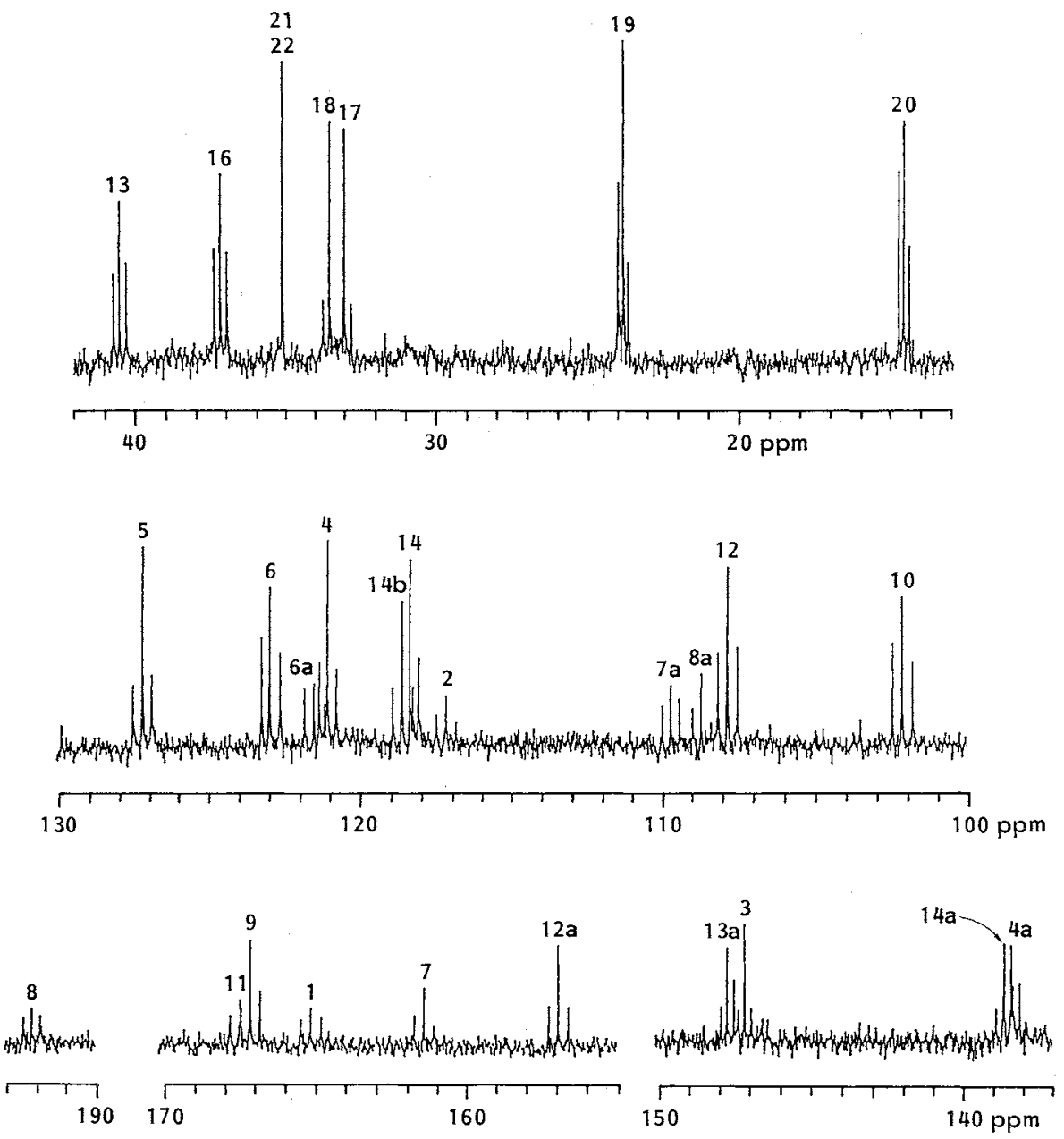

The chemical shift assignment of ${ }^{13} \mathrm{C}$ NMR signals of benastatin A sodium salt was determined by the aid of the $\mathrm{HMBC}$ (heteronuclear multiple bond connectivity) spectrum. Arrows indicate the enriched carbon signals in the ${ }^{13} \mathrm{C}$ NMR spectra of $\left[1-{ }^{13} \mathrm{C}\right]$ and $\left[2-{ }^{13} \mathrm{C}\right]$ acetate-labeled benastatin $\mathrm{A}$ sodium salt. Enrichment ratios and ${ }^{13} \mathrm{C}-{ }^{13} \mathrm{C}$ coupling constants of $\left[1-{ }^{13} \mathrm{C}\right],\left[2-{ }^{13} \mathrm{C}\right]$ and $\left[1,2-{ }^{13} \mathrm{C}_{2}\right]$ acetate-labeled benastatin A sodium salt are listed in Table 2. Enrichment ratios were calculated from the relative intensity of $\mathrm{C}-21,22$ as 1.0 . In the ${ }^{13} \mathrm{C}$ NMR spectrum of $\left[1-{ }^{13} \mathrm{C}\right]$ acetate-labeled benastatin $\mathrm{A}$ sodium salt, fourteen alternating carbon signals except the signal of gem-dimethyl carbons $(\mathrm{C}-21,22)$ were enriched by ${ }^{13} \mathrm{C}$ incorporation. A similar experiment with sodium $\left[2-{ }^{13} \mathrm{C}\right]$ acetate enhanced the ${ }^{13} \mathrm{C}$ NMR signals for fourteen carbons adjacent to the first set. These data suggest that acetate is incorporated into benastatin $\mathrm{A}$ by the way of a polyketide intermediate.

In regard to $\left[1,2-{ }^{13} \mathrm{C}_{2}\right]$ acetate-labeled benastatin $\mathrm{A}$ sodium salt, twenty-seven carbon signals were enriched and flanked by satellite signals owing to the ${ }^{13} \mathrm{C}-{ }^{13} \mathrm{C}$ coupling of intact doubly-labeled acetate units as shown in Fig. 3. Acetate arrangements proved by $J_{\mathrm{cc}}$ are shown in Fig. 4. 
Table 2. Incorporation of sodium $\left[1-^{13} \mathrm{C}\right],\left[2-{ }^{13} \mathrm{C}\right]$ and $\left[1,2-{ }^{13} \mathrm{C}_{2}\right]$ acetates and $\mathrm{L}-[$ methyl$\left.{ }^{13} \mathrm{C}\right]$ methionine into benastatin $\mathrm{A}$ sodium salt.

\begin{tabular}{|c|c|c|c|c|c|}
\hline \multirow{2}{*}{ Carbon } & \multirow{2}{*}{$\delta$} & \multicolumn{4}{|c|}{ Enrichment ratio } \\
\hline & & I & II & III $\left(J_{\mathrm{cc}}, \mathrm{Hz}\right)$ & IV \\
\hline 1 & 165.1 & 3.6 & 2.0 & $4.4(66.8)$ & 0.9 \\
\hline 2 & 117.2 & 1.4 & 3.3 & $4.3(64.6)$ & 0.8 \\
\hline 3 & 147.1 & 2.2 & 0.9 & $2.6(42.9)$ & 0.8 \\
\hline 4 & 121.1 & 1.5 & 3.3 & $4.0(55.9)$ & 1.1 \\
\hline $4 a$ & 138.3 & 3.6 & 1.5 & $3.0(55.9)$ & 0.7 \\
\hline 5 & 127.2 & 1.5 & 4.6 & $3.8(62.3)$ & 1.1 \\
\hline 6 & 123.0 & 3.1 & 1.1 & $2.9(62.3)$ & 0.8 \\
\hline $6 \mathrm{a}$ & 121.5 & 1.4 & 3.2 & $4.4(66.5)$ & 1.2 \\
\hline 7 & 161.3 & 2.9 & 1.2 & $2.7(66.5)$ & 0.7 \\
\hline $7 \mathrm{a}$ & 109.7 & 1.5 & 2.8 & $4.4(55.9)$ & 0.6 \\
\hline 8 & 191.9 & 2.3 & 1.3 & $2.8(55.9)$ & 0.7 \\
\hline $8 \mathrm{a}$ & 108.6 & 1.2 & 2.2 & $3.3(60.8)$ & 0.7 \\
\hline 9 & 167.1 & 2.4 & ND & $3.1(60.8)$ & 0.3 \\
\hline 10 & 102.3 & 1.4 & 3.4 & $3.4(66.0)$ & 0.8 \\
\hline 11 & 167.8 & 3.0 & 2.0 & $3.6(66.0)$ & 0.8 \\
\hline 12 & 108.0 & 1.4 & 2.7 & $3.5(64.0)$ & 0.7 \\
\hline $12 \mathrm{a}$ & 156.8 & 2.8 & 1.0 & $3.2(64.0)$ & 0.5 \\
\hline 13 & 40.5 & 1.3 & 3.3 & $3.6(42.4)$ & 0.9 \\
\hline $13 a$ & 147.7 & 3.6 & 1.4 & $3.5(42.4)$ & 1.1 \\
\hline 14 & 118.3 & 1.9 & 4.8 & $4.4(55.3)$ & 1.2 \\
\hline $14 a$ & 138.5 & 3.4 & 1.8 & $4.4(55.3)$ & 1.2 \\
\hline $14 b$ & 118.6 & 1.5 & 4.7 & $5.0(66.8)$ & 1.0 \\
\hline 15 & 176.6 & 5.4 & ND & ND & ND \\
\hline 16 & 37.2 & 1.3 & 3.1 & $3.2(42.9)$ & 0.9 \\
\hline 17 & 33.0 & 3.0 & 0.8 & $2.0(45.0)$ & 0.8 \\
\hline 18 & 33.5 & 1.8 & 5.7 & $3.3(45.0)$ & 1.5 \\
\hline 19 & 23.8 & 3.3 & 1.3 & $3.4(34.2)$ & 1.0 \\
\hline 20 & 14.6 & 1.4 & 4.5 & $4.1(34.2)$ & 1.1 \\
\hline $21 ; 22$ & 35.1 & 1.0 & 1.0 & $1.0(-)$ & 13.6 \\
\hline
\end{tabular}

I: $\left[1-{ }^{13} \mathrm{C}\right]$ acetate, II: $\left[2-{ }^{13} \mathrm{C}\right]$ acetate, III: $\left[1,2-{ }^{13} \mathrm{C}_{2}\right]$ acetate, IV: L- $\left[\right.$ methyl- $\left.{ }^{13} \mathrm{C}\right]$ methionine. ND: Not detected.

On the other hand, the ${ }^{13} \mathrm{C}$ NMR spectrum of benastatin A sodium salt derived from $\mathrm{L}$-[methyl$\left.{ }^{13} \mathrm{C}\right]$ methionine indicated the enhancement of carbon signal only at gem-dimethyl carbons (C-21, 22) as shown in Fig. 2. In Table 2, enrichment ratio of the signal was calculated from the relative intensity of $\mathrm{C}-19$ as 1.0 .

From the above results, the 8-oxo-3-pentyl-
Fig. 4. Building blocks for benastatin A.<smiles>CCCCCc1cc2ccc3c(O)c4c(cc3c2c(O)c1C(=O)O)C(CC)(CC)c1cc(O)cc(O)c1C4=O</smiles>
benzo $[a]$ naphthacene-2-carboxylic acid of benastatin $\mathrm{A}$ is derived from a tetradecaketide intermediate due to head-to-tail condensation of fourteen intact acetate units from $\mathrm{C}-20$ to $\mathrm{C}-15$. Furthermore, the gem-dimethyl carbons $(\mathrm{C}-21,22)$ are introduced from methionine-derived methyl groups. The building blocks of benastatin A are shown in Fig. 4. Among Streptomyces metabolites, the introduction of two $\mathrm{C}_{1}$-units onto the same carbon has been reported in biosynthetic studies of resistomycin ${ }^{7)}$ and aplasmomycin ${ }^{8}$. 


\section{References}

1) Aoyagi, T.; T. Aoyama, F. Kojlma, N. Matsuda, M. Maruyama, M. Hamada \& T. Takeuchi: Benastatins A and B, new inhibitors of glutathione S-transferase, produced by Streptomyces sp. MI384-DF12. 1. Taxonomy, production, isolation, physico-cheinical properties and biological activities. J. Antibiotics 45: 1385 1390, 1992

2) Aoyama, T.; H. Naganawa, Y. Muraoka, T. Aoyagi, T. Takeuchi \& Y. Ittaka: Benastatins A and B, new inhibitors of glutathione S-transferase, produced by Streptomyces sp. MI384-DF12. II. Structure determination of benastatins A and B. J. Antibiotics 45: $1391 \sim 1396,1992$

3) Gerber, N. N. \& M. P. LeChevalier: Novel benzo[a]naphthacene quinones from an actinomycete, Frankia G-2 (ORS 020604). Can J. Chem. 62: 2818 2821, 1984

4) Yasuzawa, T.; M. Yoshida, K. Shirahata \& H. Sano: Structure of a novel $\mathrm{Ca}^{2+}$ and calmodulin-dependent cyclic nucleotide phosphodiesterase inhibitor KS-619-1. J. Antibiotics 40: $1111 \sim 1114,1987$

5) Gomi, S.; M. Sezaki, M. Hamada, S. Kondo \&. T. Takeuchi: Biosynthesis of benanomicins. J. Antibiotics 42: $1145 \sim 1150,1989$

6) Kakushima, M.; Y. Sawada, M. Nishio, T. Tsuno \& T. OKı: Biosynthesis of pradimicin A. J. Org. Chem. 54: $2536 \sim 2539,1989$

7) HöFLE, G. \& H. WOLF: Isolierung, ${ }^{13} \mathrm{C}-\mathrm{NMR}$-Spectren und Biogenese von Resistomycin und Resistoflavin aus Streptomyces griseoflavus B71 (Actinomycetales). Liebigs Ann. Chem. 1983: 835 843, 1983

8) Chen, T. S. S.; C. Chang \& H. G. Floss: Biosynthesis of the boron-containing macrolide antibiotic aplasmomycin by Streptomyces griseus. J. Am. Chem. Soc. 103: 4565 4568, 1981 